\title{
The Variation of Javanese Islamic Society in the Existence of Paranormal
}

\author{
M. Dimyati Huda ${ }^{1}$ \\ ${ }^{1}$ Sekolah Tinggi Agama Islam Negeri Kediri \\ E-mail: ${ }^{1}$ rofikatul123@gmail.com
}

Received: 29 September 2017; Revised: 1 November 2017; Accepted: 1 November 2017

\begin{abstract}
Abstrack
Before some great religions come to Indonesia, there are some religion assured such as animism, dynamism. It trusted by Javanese until now. So that, they come to the paranormal to solve their problems. That ability is opposite with the syariat of Islam. Based on it, the most important problem should be investigated is the society of Islam who come to the paranormal, their belief that this is part of Javanese Islamic society in solving the problem and changing social life. The purpose of this study is to analyze variance Javanese Islamic society in its alteration and development in existence of Paranormal in traditional and modern life. This study was done in Sumberingin, Sanankulon, Blitar, East Java. The object of this study is to Paranormal ability. The Islamic society life is influenced by the traditional Java belief taught by their great-grandparents so that the myth of the invisible power of human can influence social life. There are three kinds of religion variation such as Islam Abangan and Islam Santri, yet Santri divided into young generation and old generation that in this study categories into Modern Santri and Traditional Santri .
\end{abstract}

Key words: society; Islam; java; paranormal;

\section{Introduction}

Before some great religions come to Indonesia, there are some religion assured such as animism, dynamism. Animistic is the sense of belief in spirits inhabiting the natural objects and as worshipping the natural objects (Usop, 1978; Rosler, 1990; Maarif, 2014). On the other hands, dynamistic is a belief to things that have an invisible power. Dynamic in the religion and belief is a devotee to unseeing soul (Anisah, 2012).

Accomodative Islamic Nusantara can be found from the history of Islam interaction factually come from Tanah Hijaz, an area located a thousand kilometers from Nusantara that thou- sand years believe to animism and dynamism, then Himduism and Buddhism as a belief before Islam (Darajat, 2015: 68). Islam in Archipelago is so accommodative to local tradition, much of observers evaluate Islam in Nusantara is not real Islam just than Islam in the Middle East (Mujabuddawat, 2016).

Indonesian people think and act are pushed by invisible belief and fill all the nature to bring to the balance (Weni, 1999). The balancing should be kept, when it disturbed should be recovered. Recovering that condition materialized in ceremony, prohibition or ritus. Simuh (2003) said that before Hinduism influence Indonesia has lived conductively 
with the animism-dynamism as a root of religious and the law of tradition as social institutions, the law of tradition show that Indonesian great-grandparents has lived conductively behind administration or tribal council, although it is in the simple form.

Animism and dynamism as a root of Indonesian culture, especially Javanese is enough to have the foundation of influencing of cultural development. Based on it, there is Indonesian people who admit that they are Islam, but their attitude is still influencing by Indonesian religion that cannot change by foreign religion (Bakker, 1976). So that, Islam in Indonesia can be said as the result of dialogue and dialectical between Islam and local culture then show the Islam that special in Java (Muqoyyidin, 2012).

Although in the early Islam come to Indonesia brought by merchants with the strong Islamic culture. Appropriate to Puspitasari (2012) that Historically the Southern Arab traders had developed trading relations with communities around the Gulf of Persian and Nusantara (Indonesian archipelago). The Arabs navigators and trader came to Nusantara for the first time to Aceh, then Palembang, at around 18th century, to Java in 1820 , and to east Indonesia in 1870. The migration of people from Hadramaut to Nusantara was intensified after the steamship serviced East- and East-Asia with Arabia since 1870. During this era there were six large Arab colonies in Indonesian cities: Batavia, Cirebon, Tegal, Pekalongan, Semarang and Surabaya (van den Berg, 2010; Unit Dakwah Masjid Al'Firdaus, 2010).

Javanese behavior is influenced by some ulama that spread Islam in Java. They are called Walisongo. The legend of Walisanga is one of the cultural heritage that still thrive in the Java community. Walisanga known as the holy figures of nine people who spread Islam in Java, who lived in the 15 'th century. Walisanga presence marks the end of the dominance of the Hindu-Buddhist in Indonesia, which was replaced with the teachings of Islam. Walisanga live in the northern coast of Java. This location is a gateway of Islam in Java (Budiarto, et all, 2016). The term of Walisanga called as figure that very respected by peoples. The meaning of 'respect' in the Wali, has been instilled by par- ents and religious leaders (Suprapti, 2014).

So it's not amazed in the Javanese life, we often find people do the truly syariat, but they still respecting and counting the day, offering in social integration that they think it is important, eulogizing duty, visiting grave of parents and ancestors.

In this level of ethical Javanese have sincere aim that not be pointed to egoistic, except placed other interest on self-interest. It related to wedding process as a sacred thing and related to service of bureaucrat of Kantor Urusan Agama. That service need an innovation to make the society be satisfying and it is not opposite with the religion and culture in Indonesia.

Related with statement above, the variance of Javanese Islam society divide into three, abangan, santri, and priayi with the different characteristics. Three variance of that religion is called The Religion Of Java. (Geertz, 1981; Syam, 2007).

In this time the society change. The alliteration that is caused by various power, both inside and outside, has caused what people called and the culture are different. Javanese in Mojokuto are not easy identify their neighbor as "abangan" or "santri" or "priyayi", both at that time is called santri and now as priyayi (priyanisasi santri) or before priyayi now it changes to be santri (santrinisasi priyayi), in spite of the fact because the old characteristics be a monopoly some certain group that change to be general practice. Beside that, the bluring of old cultural limitation can be appeared by new cultural limitation based on different construction limitation. This process change limitation of groupo and culture that define in the group or other group (Abdullah, 2006: 16).

Facing challenge of development of western culture, there are three variance of Islam in Java and Indonesia generally. They are Islam Kejawen variance, Traditional Islam variance, and Modernis Islam variance. They take role in build Republic of Indonesia. (Simuh, 2003:114).

Besides that, the society empirical reality in this study implementing has happened the aliteration and development in the priyayi that change to be santri (santrinisasi priyayi), this aliteration happened when they entering their children to the pesantren same with Islam Kejawen (or it called abangan in this study), from that fact Javanese 
Islam society in this study implementing devided into "Islam Kejawen, Modern Islam, Traditional islam", the people come to paranormal come from several social classes and several profession, besides that this location chosen by the researcher because there are some Islam people concern with religion and also to be a paranormal (researcher called it) or dukun.

The other studies to self-interest of Javanese Islam society in the several class that come to paranormal specifically unpublished and unimplemented.The surveys show that nowadays, paranormal beliefs are widely held by many people (Surmeli\& Saka, 2011). Tobacyk (2004) indicated that psychokinetic phenomena could be classified as paranormal. Typical examples of paranormal beliefs are unidentified flying objects, ghosts, the Bermuda Triangle, Pyramid Power, astrology, communicating with the dead, faith healing, telekinesis, extrasensory perception, out of body experiences and monsters (Farha\& Stewart, 2006; Lewis, 2002; Priest, 1995; Williams, et al., 2007).

Based on the statement above, the most important problem should be investigated is the society of Islam who come to the paranormal, their belief that this is part of Javanese Islamic society in solving the problem and changing social life. Javanese Islam society is part of Indonesian society that cannot separate with the great-grandparents culture. Indonesia is one of the plural and multicultural country because there are so many ethnic, language, religion, culture, etc. (Mujiburrahman: 2013). The purpose of this study is to analyze variance Javanese Islamic society in its alteration and development in existence of Paranormal in traditional and modern life.

The researcher hopes the finding of this study can give the positive effect to society to solve their problem using this method of expert from paranormal, so that it need theory of new science for the society, or to be the prospect knowledge of culture in the next time, so that become a semantic knowledge acomodation scientificly in Javanese, which will become obligatory curiculumin social faculty or branch of other science, on the contrary, if it is called science pseudo that not give the positive effext to the mindset ad behaviour to the problem society, so this study will be the explanation to the society rasionallity, it's the time to society be more creative with the new culture that more productive in reaching developmental culture Javanese Islam society scientifically and rasionally.

In addition to the reflection culture between Islam and Java in development and alteration of society and some myth dimension itself, it expects that there are the finding that local culture can help culture or outside religion to develop to be strong in the local area as long as that outside culture can accept and become a part of local culture. Islam in Java, in the behaviour mystical rational of dukun kejawen oriented to spiritual life based on Islam values that have appropriated with Java mystic. (Purwadi: 2004:15).

\section{Material and Methods}

This study is qualitative research, which use emphasizing to the ethnograph method that in the antropological cognitive want to try understanding how the people percept the world by reviewing; how they communicate. (Mulyana, 2001). This qualitative research is ethnigraph. Ethnography popular with "uraian tebal" (thisk description) which find by ethnograph when test the culture based on this perspective is a interpretation to the definition life "akal sehat" which is complicated and difficult to explain. The aim of ethnograph is doing experiment together define that; the role of culture counting and drawing the new definition, for readerand other people. (Moeleong, 2000).

The location of this study is decided purposively based on the data that is the area which have variative society or islam society is heteregenous and have some religious people worked as a paranormal. Finally the location which become the research location is Sumberingin, Sanan Kulon, Blitar, East Java. The object of this study is the behaviour of paranormal.

\section{Results and Discussion}

\section{Variance of Islam society in Sumberingin San- an Kulon}

This research was implemented in Sanan Kulon, Blitar, East Java which have some village especially Sumberingin, the society consist of labouring and farming and some of them are seller, employee, TKI and TKW and also as an offi- 
cial territory. There are no social classes from the religious social perspective, except village society with the traditional religious activity. It can be seen from their activity in doing religious activity so many use the ritus ceremony which use offertory and others.

But there are some aliteration in the life system because of electric, street asphal, education, and some of them to be TKI or continue the study. But their mindset as a traditional people still keep the culture, although young people get the modern life because of study out of the city. It does not help their mindset. So, NU society and a little bit Muhammadiyah and Nationalis in culture concepting as culturesphere or culture space which unite various social classes, still defend.

The variance of Sanankulon people is not significant in the differences except just do the syariat sholat in a day, because they are assimilate each other., based on Geetz, in some of his creations is a long explanation that show the deep result or partisipation observation, so that can explain events deeply and the definition itself.

Based on the study of Geertz in Mojokerto; based on the trust, belief, ethical presensy, the political idiology is very clear, that they are divided into three classes such as abangan, santri and priyayi with the different characteristics. They are called The Religion of Java. In short, priyayi emphesize Hindu aspect and be assocoated with bureaucracy. Abangan is farmer and santri is merchant.

Different with Sanan Kulon society, although they can classify as santri and abangan, that santri Islam society straight to do syariat. Meanwhile priyayi categoried by Geerts as bureaucracy cannot be shown the devided of the society of Sumberingin Sanan Kulon, because in this society, both abangan and santri become bureaucracy in the status of their job, moreover as an abangan entered their children to the Pesantren area or Islamic school, as follow: Madrasah Ibtidaiyah, Tsanawiyah or university of Islam.

Related with this, someone who entered her children to the Islamic school said: "I am a fool of religion, because I just graduated from Junior High School, then I worked to help my parents, so I don't have opportunity to come back to school, I hope it will not happen to my kids, so I entered my kids to Madrasah." (Sukoco's interview; 5 September 2007)

From this stetement, there iss no variance happened in Geertz' study, added Geertz, santri is ritual dimensions and mystic piety of traditional santri as product of syntetic Islam and religion of Java before Islam. Based on traditional santri's opinion live in the cloistered that most of them isolated from orthodox "Middle East", so their opinion of Islam more Java than Islam then this santri called "an old santri", the fact that often called as "orthodox", the fact it is not the most Islam of Java Muslim, but less than it, create minimum movement from the traditional systems whare there is animism Hindu elements, Budha and Islam.

It founded in the balance to the situation where Islam and world opinion that associated fully gathered in the internalization independent so that it can lead behaviour more than put a comment inside to hide the right values in deciding individual behaviour.

Geertz said that; theology, Hadits and branch of Islam doctrin are taught, but the content of it still be warried, start from the general up to fundamental can be understood by santri, except for the smart student because when they learn it by the skill and the good language but they do not understand at all. (Wood, 2004)

Geertz interpretation is not wrong, not all of the Islam in Sumberingin Sanan Kulon called by santri understand the foundation, but most of them who learn deeper in studying of Arab include Tafsir, such as; the study that be taught in Islamic University, so that they classified as modern santri till get the bachelor of religion that graduated from IAIN, STAIN, and UIN and others.

However not all of the santri classified as modern can do the alteration of mindset of traditional or old santri in Sumberingin Sanan Kulon, if the classification of variance in this are separate from obey santri and unobeyed santri as abangan, so Islam santri itself can be divided into relatively modern santri and traditional santri.

One of traditional old santri who her kids study out of the city and more modern from older as master of religion worried with the new thinking from her kids, "'at the begin I worried of my 
kids after he/ she graduated from University because he/ she always be little the tradition like offertory, visit the grave, tahlil, etc. But I just see it on her discussion, in fact he still aware of the culture itself. (Interview: Nurhadi, 2 September 2007).

From this discussion, it can be seen that the effort of old people to face the modern thinking of young generation, to still save the culture and cannot accept the alteration brought by young generation or santri and it can be seen from the percentage of modern santri a little bit more than abangan or traditional santri. The result of election show that National Party more be interested such as PDIP and Demokrat and then Traditional Islam Party such as PKB, PPP then small party such as PAN and PKS.

When it classified into some part, there will be the variance in Sumberingin Sanankulon Blitar cannot separate with the traditional history. Since National Movement in Indonesia from Kejawen Islamic Culture appear two groups of secular Nationalis and Communism which radical secularsm or Atheis. Meanwhile Islam Pesantren classified into two part that are modern Islam and traditional islam and this differences happened so sharp in the past so that make schism in the Islam society.

That condition make difficulty to unite Islamic Nationalist Movement as an alternative for secular Nationalism of Soekarno Hatta, in fact that be shown by experience and NU influence a organization built in 1926. This group get the major support from local Ulama that oppose secular Nationalism and Islam Modern. NU argue Pan-Islam consideration believe that Wahabi movement in Arabian as bid'ah and express good opponent to Muhammadiyah and Sarekat Islam (Simuh 2003: 116).

Based on statement above, abangan group which have the concept of limited islamic will be more easy to be influenced by West culture, although they are not doing their culture of Java, it will be more easy to go to something secularsm or nasionalism, when we are to be TKI or TKW will accepted to leave syariat Islam such as not doing fast, sholat, or bathe the dogs, just than santri , although they aim to the National but they have Islam Nationalism system.

The tolerance in this place is very visible so there is no conflict when they have different understanding and behaviour in realising Islam, because their expression of "Akmaluna Walakum akmalukum" will be the representation. Despite they have diffent understanding, they are still in the same mosque, ritual meal, at field, the the harmonic relationship, so whatever the varience but they still do their culture will be make their life in society be harmonious.

There are some variances that having same great-grandfather, that is; full of trust of Java culture that is not easy to be loosen with the new culture. The power here, that all of the variance agree to save their own culture.

\section{The society profile that visited Paranormal in Sumberingin Blitar}

This study focus on investigate the Paranormal in Sumberingin Blitar that is located in the area of the researcher in Ringinsari, Sumberingin, Sanankulon, Blitar.

The researcher is Islam that was born in 1974, and when he was young he study at MI Arrofmad that NU school, then he went to some Pesantren to learn more religion in and some of them are Pesantren Salaf, in 1986 in Pesantren of Alkamal Kunir Srengat Blitar, he also went to some educational places and the holy place in south ocean.

When he come return from some Pesantren and formal education, in 2000 he become a civil servant lecturer of STAIN Kediri, and help each person who need him. He has ever use his skill and capability since his parents still alive that was also become a Paranormal.

In fact, Paranormal also did what the people did like sholat, lead sholat in Mushola and meet some guests in all the time, because we are not decide the time to visited home, but all the time in 24 hours the house will be open because his father said that we have be sincere in helping people. He remembered his father said "People problems will not know the time, in the morning, mid day, and also mid night, in the some emergency cases like gave birth that needed water and have to as soon as possible geit it. So, $i$ have to wake up from my short sleeping."

Paranormal does not allow to be lazy, it is difficult to be done by other people, we have ever think: "something that I cannot imitate from my father is when we have to meet all of the people 
in all condition, although we just sleep at 3 or at the midday, it is so hard for me beacause I have to leave my own business, but it is a destiny what we have done."

We are not want anything and also never choose, differentiate the guests, all of the people should be help as long as for the good thing. The researcher has ever met the new guest, advice, and to make the guest return home immediately, because the guest want to me to make someone wretched. In the next time, he was comeback (admit from Surabaya) and I gave the same answer that all the guest did not allow to come three times, in the last time, he gave should do Istighfar, then he did not return.

It make us to be sad, because basicly he has ever said: "By God, I never hope people come to me, especially in the morning, I have to meet the guests all the time till night, and exactly they bring their problem. All of their problems make me sad, when they just need happiness prayer, or find a knowledge, it's no worry, but they come to bring their problem about family, their kids, an employee who has a problem with the boss, and also ask lucky number of gambling."

In other occasion, related to what they have done is not from theirselves, but God do it. "Sometimes, I feel confuse why people just come here when will be operated, they did not do it because the doctor analyze they are healthy. When kids are crying and cannot stop alhough her father is a doctor and her mother is a midwife, at 3 come and she stop to cry, moreover she was sleep well. When I was young, my father told me that I will can "mendamu" (praying, then blow to the water or kids) then he/she will be better and when she/he was cring, they will stop tyo cry. Why? Because your tonge is different with other. You have fire tongue, your symbol is full moon because you will be loved by people like strong horse in all problem said my uncle. When I entered my room to solve my guest's problem, suddenly like someone show me what should be given, so the same problem will be different method. This come from my father, so that we can do it too."

From all the explanation, in location od this study some of things cannot explain rationality from Paranormal itself, except we bring to
God. My father said: "I don't like doing something that related to the astral, such as evil, it means that it is not good by people that do the wirid have the aim to the evil, because we have be sincere only to Allah, morover ask evil's help, it is forbidden in syariat of Islam; in 1965 there are some Ulama figure in Blitar being asked to practice Wirid Hizib Nashor, including me, because related to the safety in rebellion of G $30 \mathrm{~S}$ PKI, because some of Islam figure are threated, this room "weather" (situation) hot and sometimes appear human shadow and it seen by most of people, this case are lost when Wirid is stop, despite we think that they are angels which to be the guardian, but it is possible if there are others in the Hizib nasor. We should believe that when we do it purely to Allah, so assured that all of them are from God."

My father never used the evil to do Wirid and his prays, but the end of it some of them like it. It happen out of the aim and plan, like flow of water, when the water flow in the clean pipe so the water will clean too, in the contrary, when the pipe flow in the drain, so that it will appear something unhealthy to be drunk.

There are some method used by people to do the ritual in solving the problem faced when a Paranormal expell the evil that disturb that people believe expellit by scared motivation, and also expell it peacefulli without violence,Islam belief that evil is the real human enemy so literallythe human forbid to compromise, so God values should be first.

It rather different with us as long as spiritual that we have arrived by bunda ratu pantai selatan, and as our good intend sometimes we do spiritual communication with bunda ratu as hablu minal jin without hoping the reward except in purpose to increase the obeys to Allah SWT. So that if there is no pleased to some souls whi disturb the human need to communicate first before let them go or some of them are the creature that want to be complicated.

In realizing this method, it is so slight between love and scary, sometimes love and scary appear together. So that people who work in the secret thing should be able to distinguish the right way and wrong way, as Paranormal did, our father is so real and just because of helping each other and sincere of God.

When he asked by researcher about what is 
the history of society asked to help to solve their problem, he explained: "there are so many kinds of people come here and they cannot solve their problem. Some problems like family, give birth, and find a mate. Other case like they will open a new business, keep the position, free from the punishment, and others. This occurs because they are confused of finding the way to solve the problem, and they think that we are an older people, should be conciliate all of the problem such as: in the morninga women came and said about her husband mistakes, in the evening, her husband do it too, so we try to deduct their emotion and in the next they are harmonic again. We still found this problem up to now."

Blitar people as part of Java in South are related to values of old culture that are Demak, Majapahit, and Mataram, so the mystical culture such as dukun is very popular. Both central of city, village, mountain range are close to mystic. Dukunism appears because some of Javanese looking for real life essense and the real of universe. Javanese lean to find the balance with domain and heart, that they often do by metaphysical ways. (Purwadi, 2004:1).

That ways are judged as inheritance of ancestor that should be saved, moreover, that traditions have glorious values than modern people such as implanation of pin (susuk). "the method of implanation pin is not new, as the people effort to strength or authority, although it is unknown in Islam Al Qur'an and hadits, but we still use Asma-Asma Allah, and this ritual is an activity that Tabib done in the past, it does not offend, and it is part of efforts."

Beside of gold, the researcher found that there is a future effect of implanation of pin, such as implanation of steel, iron or others. The explanation: "because the implanation except gold, the skin will be change into black, or cause of illness "keju linu" (the body is strong but will feel pain), so that it can be said that there is mudlorot in the future".

So, the activity of Paranormal that appear the mudlorot will not do again, another explanation of where the method is gotten, is not from Al-Qur'an - Hadits but the method of ancestors so that there isa culture comes from another Islam, just the prays still use the Tauhid method. As the first principle of Pancasila states, belief in the Almighty indicates that the Indonesian people must be theocentric, which in Islam was defined as Tauhid(Usman, 2017).

One day we came to the grave of our parents. We opened the one box, two box of telon flower and wipe "bloreh" (as a complement of fragrant that stick to the leave) both in two top grave (head) and under (leg) then Paranormal read Surah Al-Fatekhah that be purposed to his parents once time, then continue to read Surat Ikhlas three times, Surat Al-Alaq once time, Surah An-Nas once time, read Laa ilaaha illalloh $\mathrm{Hu}$ Allahu Akbar Bismillahirrohmaanirrokhiim between each Surah, then continue to read Surah Al -Fatekhah again then read Ayat Kursi once time, at the last, pray for both father and mother. When we have much time, we are also visited other family's grave.

That the activity we do to keep and spiritual communicate first to the parents before we communicate to the others souls.

\section{The Variation of Javanese Islamic Society in the Existence of Paranormal}

The object of this study are; people who come to paranormal and people around of paranormal, both they visited paranormal and in the daily activity related to the Islam Java culture such as; offertory, count the days, etc.

People who visited paranormal include some variance of profession, involve of problem. People belief to the paranormal existence, not only investigate related to mindset, but also the background of ancestors in the history of Java culture with its theory and philosophy that is create myth and sense of Islam Java to paranormal.

Mindset will create life philosophy. Javanese philosophy identical with life of Java. Mindset of Javanese is the preciritate of spiritual experience. That experience is very fundamental so that create concept of life. When it leaved, it does not complete in their life.

Javanese myth is much enough, myth is holy story in symbolic form that tell about real events and imaginer of origin of the alteration of universe and the god world, the power of nature, human, heroes, and society.

The myth characteristic that develop in Javanese as follows: (1) myth is holy or sacred, related to the adorable figure, such as Wali or Ratu Kidul. (2) myth can be found in myth world and 
not in the real life or in the real past. (3) so many myth in Java that show the important events. (4) the rightness of myth is not important, because the firmament and mth era are not ralated to the possibilities and limits real world.

Javanese myth so mavariance, that is part of life philosophy and old culture, it can divide as follows, first, there are myth of prohibition, if it be broken, Javanese are afraid to accept the bad result. For example, Javanese are not allow to marry with misan (misanan), someone who have same area with and geing (wage and pahing).

If it be broken will be consequenced with the generation or the the bad events by two family. That is why people in Blitar if they want to marry will visit paranormal to solve the problem and count the best day for married.

Second, associatif myth. This myth sometimes happen in the dream. So that Javanese called good dream and bad dream. When they got bad dream Javanese will trust they will get disaster, then they do offertory. For example the dream of flood, it menas that they will get the bad things.

Third, legend and history, it has strong legitimation in Javanese. For example; kanjeng ratu kidul, aji saka, syekh subakir, that is all the mystic legend that influence Javanese spiritual. Mythological figure are believed have supranatural power, so that it needed to be respected. Sometimes Javanese Islam activity use wasilah reward Surah Al Fatehah to Syekh Abdul Qodir Jaelani.

Forth, the myth that is syirikan (something that must be avoided). This myth is still associatif, but the major emphesize in the bad thing that will be done, when it be broken, there is the bad effect will be occured. For example in the wedding party, Javanese will not take Kumbakarna Gugur and Baratayudha as the theme of wayang or the sad story. Likewise campursari, Javanese will not sing randha kempling (the new widow), because they afraid that be divorced, so that it is very avoid. In wedding party, the best to use the theme wedding or decrease of revelation. (Endraswara; 2006, 196).

Javanese Metaphysics philosophy can be considerated by ontogenistic, mystic, and phi- logenistic (process of evolution). The opinion of ontogenistic and mystic aim to the existencialist that is the real experience occured by someone, and itis not just concept. Whereas philogenistic concept related to the human life. Life is movement. This statement show that human will be do evolution till the end, it called the journey of life. This process occured because the human have a hope, like see the last light, that it far but they still have spirit to live. That beautiful light make the Javanese always try to find peace of soul.

Javanese is unique, so many people said that Java is exclusive. That characteristic make controversy. So many questions and embitered. That's whay Javanese hold out of test, beat, it always make controversy.

The great of Javanese because they have good philosophy of life and complex that care of culture and the power of Javanese is on the philosophy of madya; that is the direct statement from the ancestors, so people is rarely to pay attention. The philosophy of madya life comes from soul concept of Javanese which implemented on (solah bawa muna-muni dan and pratingkah). It means that by attitude and behaviour full by transparant and sasmita. So that, it need to understanding more by using soul and feel. (Endraswara: 2006, 48).

The original culture of Java that transendental more lean to animism and dinamism, the great alteration occur when Hindu and Budha comes from India. The Indian Culture influence the Javanese culture, as follows: trust system, art, literature, astronomy, mythology and science. Hindu Budha culture is spread by language that is sanskrit (Purwadi: 2006: 19).

This culture make the Javanese consideration till now, which along with the alteration based on social development. In Sumberingin, there are Islamic Javanese society that live with all of the Javanese tradition, such as; offertory, visit the grave and other habitual, but some of them change their life style because of education or beyond information, besides that, in the location of this study, there are some religious figure that is also become a paranormal, they are often visited by people.

In this reality people think that paranormal is not always related to the charlatanism, but more trust as a person who people can ask the problems or conficts. 
In the alteration era that occur to the people is not change their habitual to come to paranormal to solve their problem, but there are tradition to solve the problem by visiting the paranormal, because that is become a habitual and also limitation of rational that do them together, such as, when the women gave birth to the midwife, her husband or parents comes to paranormal to ask the water that have given the prays for continuity of giving birth.

People belief of paranormal can be more strange when paranormal use some methods or solve by rational discussion, like the suggestions given by paranormal as the religious figure that always use the rational based on religious theory, it makes the people more quiet after back to paranormal.

\section{Conclusion}

From the explanation, it can be concluded that the The Islamic community in the field of research in conducting its religion is influenced by the teachings and beliefs of Java previously performed by the ancestors, so there is a myth of the existence of supernatural powers outside the human self that can affect in the matter of life. In the present development, the community in this place of research is carried out there is a variant model of religious knowledge consisting of Islamic Abangan and Islam Santri, but this Santri there is a division between the older generation and the younger generation, in this category of research in mention of the existence of Modern and Traditional Santri.

\section{Suggestion}

This research is the first research at Sumberingin, Blitar, East Java. Big hope the next researcher can to do this with the larger area and deepest analyst.

\section{References}

Abdullah, Irwan. 2006. Konstruksi dan Reproduksi Kebudayaan. Yogyakarta: Pustaka Pelajar.

Al Mujabuddawat, M. (2016). Simbolisme Komplek Bangunan Situs Ki Buyut Trusmi Cirebon. Kapita Arkeologi. 12 (2): 175-190.

Anisah, F.U. (2012). Pengaruh Perilaku Bu- daya Dinamisme terhadap Kualitas Keimanan Masyarakat di Desa Mlilir Kecamatan Bandungan Kabuapten Semarang Tahun 2011-2012. Skripsi tidak diterbitkan. Jurusan Tarbiyah, Prodi Pendidikan Agama Islam, Sekolah Tinggi Agama Islam Negeri Salatiga.

Bakker, S.J. J.W.M. 1976. Agama Asli Indonesia. Yogyakarta.

Budiarto, Atiek Suprapti., Indriastjario, Sardjono, Agung Budi. (2016). The urban heritage of Masjid Sunan Ampel Surabaya, toward the intelligent urbanism development. Procedia - Social and Behavioral Sciences. 227: 601-608, http:// www.sciencedirect.com

Darajat, Z. (2015). Warisan Islam Nusantara. AlTurās, 21(1), 66-78.

Endraswara, Suwardi. 2006. Falsafah Hidup Jawa. Yogyakarta: Cakrawala.

Farha, B., Stewart, G.R. (2006). Paranormal beliefs: An analysis of college students. The Skeptical Inquirer, 30(1), 37-40.

Geertz, Clifford. 1981. Abangan, Santri, Priyayi dalam Masyarakat Jawa, terj. Aswab Mahasin. Jakarta: Pustaka Jawa.

Lewis, C.M. (2002). Investigating students' beliefs in the paranormal. Master Thesis, University of Wisconsin, Stout.

Maarif, Samsul. 2014. Being A Muslim in Animistic Ways. Al-Jāmi'ah: Journal of Islamic Studies. 52(1): 149-174.

Moleong, Lexy J. 2004. Metodologi Penelitian Kualitatif. Bandung: Remaja Rosda Karya.

Mujiburrahman. 2013. Islam Multikultural: Hikmah, Tujuan, dan Keanekaragaman dalam Islam. Addin. 7(1): 65-80.

Mulyana, Deddy, 2001. Metodologi Penelitian Kualitatif (paradigma baru Ilmu komunikasi dan ilmu sosial lainnya). Bandung: Remaja Rosda Karya.

Muqoyyidin, (2012). Dialektika Islam dan Budaya Lokal dalam Bidang Sosial sebagai Salah Satu Wajah Islam Jawa. El Harakah. 14(1): 18-33.

Purwadi. 2004. Dukun Jawa. Yogyakarta: Media Abadi.

Puspitasari, Popi., Djunaedi, Sudaryono Achmad., \& Putra, Heddy Shri Ahimsa. 
2012 Ritual and Space Structure: Pilgrimage and Space Use in Historical Urban Kampung Context of Luar Batang (Jakarta, Indonesia). Procedia Social and Behavioral Sciences. 36: $350-360$.

Priest, P. (1995). The effectiveness of instruction in scientific reasoning in altering paranormal beliefs in high school students. Doctoral Thesis, La Sierra University, Riverside, California.

Rössler, Martin. (1990). Striving for Modesty: Fundamentals of the religion and social organization of the Makassarese Patuntung. Bijdragen tot de Taal-, Land-en Volkenkunde. 146(2): 289-324.

Simuh. 2003. Islam Dan Pergumulan Budaya Jawa, Jakarta: Teraju.

Suprapti, A., Sardjono B, A. 2014, The Tradition of Living of Muslim Community Kudus Kulon, Journal of Social Sciences 10 (2) 63-73 2014, Science Publication.

Surmeli, Hikmet. \& Saka, Mehpare.2011. Paranormal beliefs of preservice teachers. Procedia Social and Behavioral Sciences. 15: 1385-1390.

Syam, Nur. 2007. Madzhab-Madzhab Antropologi, Yogyakarta: LkiS Pelangi Aksara.

Tobacyk, J.J. (2004). A revised paranormal belief scale. The International Journal of Transpersonal Studies, 23, 94-98.

Unit Dakwah Masjid Al'Firdaus. (2010), Lambang Terukir : Dalam Mengisahkan Manaqib Habib Noh Bin Muhammad Al-Habsyi Yang Syahrir. Singapore: Unit Dakwah Masjid Al Firdaus.

Usman, A. H., Shaharuddin, S. A. and Zainal Abidin, S. 2017. Humanism in Islamic education: Indonesian references. International Journal of Asia Pacific Studies 13 (1): 95-113, http:// dx.doi.org/10.21315/ijaps2017.13.1.5

Usop, K.M. (1978). Pasang ri Kajang: Kajian Sistem Nilai di "Benteng Hitam" Amma Toa, Ujung Pandang: Pusat Latihan Penelitian Ilmu-Ilmu Sosial Universitas Hasanudin.

Van den Berg, LWC. (2010), Orang Arab di
Nusantara, Jakarta: Komunitas Bambu.

Weni, I Made. 1999. Fungsi Sabung Ayam Dalam Kehidupan Masyarakat Hindu Di Bali. Disertasi Tidak diterbitkan. Surabaya: Universitas Airlangga.

Woodward, Mark R. 2004. Islam Jawa (Kesalehan Normatif Versus Kebatinan). Yogyakarta: LKiS.

Williams, E., Francis, L.J., Robbins, M. (2007). Personality and paranormal belief: A study among adolescents. Pastoral Psychology, 56, 9-14. 